\title{
Molecular Characterization, Ecology, and Epidemiology of a Novel Tymovirus in Asclepias viridis from Oklahoma
}

\author{
Byoung-Eun Min, Tracy S. Feldman, Akhtar Ali, Graham Wiley, Vijay Muthukumar, Bruce A. Roe, \\ Marilyn Roossinck, Ulrich Melcher, Michael W. Palmer, and Richard S. Nelson
}

First, second, seventh, and tenth authors: Plant Biology Division, Samuel Roberts Noble Foundation, Inc., Ardmore, OK 73401; third author: Department of Biological Science, The University of Tulsa, Tulsa, OK 74104; fourth and sixth authors: Department of Chemistry and Biochemistry, University of Oklahoma, Norman 73019; fifth and eighth authors: Department of Biochemistry and Molecular Biology, and ninth author: Department of Botany, Oklahoma State University, Stillwater 74078.

Current address of B.-E. Min: Department of Plant Pathology, University of Kentucky, Lexington 40546.

Current address of T. S. Feldman: Department of Biology, University of Wisconsin-Stevens Point, Stevens Point 54481.

Current address of G. Wiley and V. Muthukumar: Oklahoma Medical Research Foundation, Oklahoma City, OK 73104.

Current address of M. Roossinck: Center for Infectious Disease Dynamics, Pennsylvania State University, University Park 18602.

Accepted for publication 22 September 2011.

\begin{abstract}
Min, B.-E., Feldman, T. S., Ali, A., Wiley, G., Muthukumar, V., Roe, B. A., Roossinck, M., Melcher, U., Palmer, M. W., and Nelson, R. S. 2012. Molecular characterization, ecology, and epidemiology of a novel tymovirus in Asclepias viridis from Oklahoma. Phytopathology 102:166-176.

Native virus-plant interactions require more understanding and their study will provide a basis from which to identify potential sources of emerging destructive viruses in crops. A novel tymovirus sequence was detected in Asclepias viridis (green milkweed), a perennial growing in a natural setting in the Tallgrass Prairie Preserve (TGPP) of Oklahoma. It was abundant within and frequent among $A$. viridis plants and, to varying extents, within other dicotyledonous and one grass (Panicum virgatum)

yellow mosaic virus. The persistence of the virus within the Oklahoma $A$. viridis population was monitored for five successive years. Virus was present in a high percentage of plants within representative areas of the TGPP in all years and was spreading to additional plants. Virus was present in regions adjacent to the TGPP but not in plants sampled from central and south-central Oklahoma. Virus was present in the underground caudex of the plant during the winter, suggesting overwintering in this tissue. The RNA sequence encoding the virus coat protein varied considerably between individual plants $(\approx 3 \%)$, likely due to drift rather than selection. An infectious clone was constructed and the virus was named Asclepias asymptomatic virus (AsAV) due to the absence of obvious symptoms on $A$. viridis.
\end{abstract} species obtained from the TGPP. Extracts from A. viridis containing the sequence were infectious to a limited number of species. The virus genome was cloned and determined to be closely related to Kennedya
Additional keyword: Apocynaceae, Tymoviridae.
Although it has been difficult to identify virus sequences in the fossil record, there is general consensus that plant viruses appeared very early in land plants (perhaps already within the progenitors of these plants) and evolved within their hosts through hundreds of millions of years $(15,29)$. This evolution likely led to diminished disease phenotypes on their hosts prior to the cultivation of plants for agriculture $(46,58)$. The transport of plants around the world and increasing use of monoculture in agriculture, both products of increased human activity, resulted in the appearance of emerging viruses and virus disease epidemics likely based on modification of the underlying diverse extant virus population $(3,7,11,24,33,45)$. Presently, however, most information on plant viruses has been acquired from symptomatic cultivated hosts rather than asymptomatic native or wild species (60). Thus, it is important to survey and characterize the underlying diverse populations of viruses in wild plants to better understand the pattern of virus evolution and to better predict the potential of particular native viruses to infect cultivated species around the world.

Corresponding author: R. S. Nelson; E-mail address: rsnelson@ noble.org

* The $e$-Xtra logo stands for "electronic extra" and indicates that the online version contains one supplemental table. Figure 2 appears in color online.

http://dx.doi.org/10.1094/PHYTO-05-11-0154

(C) 2012 The American Phytopathological Society
The Tallgrass Prairie Preserve (TGPP), located in Osage County of northeast Oklahoma, is a 15,410-ha natural area managed by The Nature Conservancy $(1,41)$. This area has been managed to mimic natural disturbances of fire and grazing (bison and cattle) to reflect historical ecological variability $(1,18)$. The Plant Virus Biodiversity and Ecology (PVBE) project was initiated to determine the diversity of viruses within the TGPP and understand their ecologies (60). Samples from $>600$ plant species within the TGPP were harvested and analyzed for the presence of virus signature sequences utilizing various isolation methods, including capsid $(37,39)$, total nucleic acid $(23)$, and doublestranded RNA (48) procedures. Nucleic acid obtained directly or indirectly from these isolation procedures was sequenced and sequences were compared with those of known viruses in databases (39). Extracts enriched in capsids from members of the plant genera Ambrosia, Amelanchier, Amorpha, Asclepias, Carya, Cephalanthus, Digitaria, Desmanthus, Lespedeza, Melilotus, Panicum, Paspalum, Pellaea, Sorghastrum, and Sporobolus contained sequences with similarities to known members of the Badnavirus, Carmovirus, Comovirus, Panicovirus, Tombusvirus, and Tymovirus genera $(39,50)$ and unassigned genera within the families Flexiviridae and Tombusviridae $(37,50)$.

A high titer of virus signature sequences similar to those of tymoviruses was obtained from $A$. viridis samples within the TGPP (39). Tymoviruses are composed of a single-stranded genomic RNA of 6 to $7 \mathrm{~kb}$ and contain three open reading frames 
(ORFs) (22). They are present throughout the world $(27,44)$. Tymoviruses infect dicotyledonous plants, can be transmitted by beetles, and generally, but not exclusively, are associated with infections in native species rather than cultivated species $(5,7$, $19,22,25,42)$. Hosts can be perennial native plants, as in the case of Cardamine robusta for Turnip yellow mosaic virus (TYMV) (20).

Here, we report the isolation and cloning of the tymovirus whose signature sequence was observed in A. viridis in the TGPP. In addition, we provide an initial understanding of the ecology and epidemiology of this virus. To classify the virus, we cloned its genome, compared its sequence with those of known tymoviruses and explored its experimental host range, the latter to document host species that potentially serve as reservoirs should this virus evolve into a threat to crops in the region. We constructed a clone from which an infectious transcript could be synthesized and named the virus. To determine the persistence and geographical prevalence of the virus, we measured its distribution over time in the TGPP and its presence outside of the preserve. Also, its overwintering characteristic within A. viridis was examined. Sequence variation of this tymovirus between individually infected plants was determined to evaluate the potential that variation was a rapidly selected characteristic.

\section{MATERIALS AND METHODS}

Host range analysis. Images of plants from the TGPP representing multiple plant species from which field samples were collected in 2005-06 were reviewed for visible virus-induced symptoms (e.g., mosaic) using the TGPP plant information database (plant information at http://bioinfosu.okstate.edu/pvbe/ index.html) (37,39). Experimental host range analyses were conducted by extracting tissue from an $A$. viridis plant containing the tymovirus signature sequence (05TGP00351; the source plant used to clone the tymovirus, as described later). Extract was mechanically inoculated to leaves of greenhouse-grown members of the families Chenopodiaceae, Solanaceae, Brassicaceae, and Cucurbitaceae. These plants were observed for visual symptoms over a 3 -week period. Near the end of this period (3 to 4 weeks postinoculation) leaves were analyzed for tymovirus signature sequence. For both field and greenhouse experimental host samples, RNA was extracted using a mortar and pestle prefrozen with liquid N. Extraction buffer (EB) $(2 \mathrm{ml}$ of $8 \mathrm{M}$ guanidine hydrochloride, $20 \mathrm{mM}$ MES [pH 7.0], $20 \mathrm{mM}$ EDTA, and $50 \mathrm{mM}$ mercaptoethanol) was added to $0.5 \mathrm{~g}$ fresh weight of material and extraction continued as described (30). The RNA was subjected to reverse-transcription polymerase chain reaction (RT-PCR) analyses. cDNAs were synthesized using $1 \mu \mathrm{g}$ of total plant RNA and a Superscript III kit (Invitrogen). Primers TGP00337R (AAGGT GACGTTGCTTTTGAGGATCG) and Tymorep5-4 (CATGAGA ACCCAGAAGTTTCCCGT) were used to amplify the tymovirus sequence.

Virus source for propagation, characterization, and cloning. Multiple A. viridis plants sampled from the TGPP in 2005 showed no visible disease phenotype but yielded tymovirus sequences after virus-like particle isolation and nucleic acid extraction (39) (http://bioinfosu.okstate.edu/pvbe/index.html). One of these $A$. viridis plants, 05TGP00351, was the tissue source for tymovirus propagation and cloning. A tymovirus was extracted from $A$. viridis leaves in $10 \mathrm{mM}$ phosphate buffer $(\mathrm{pH} 7.0)$ and propagated in Nicotiana benthamiana by mechanical inoculation of extract after dusting leaves with carborundum. Tymovirus particles were isolated from $N$. benthamiana leaves as described (6). Proteins were separated on a $12 \%$ sodium dodecyl sulfate (SDS) polyacrylamide gel and visualized by Coomassie R-250 staining (Bio$\mathrm{Rad})$. The viral genomic RNA was extracted from purified virus particles using SDS/proteinase K-phenol (6). Viral RNAs were separated on a $1.2 \%$ denaturing agarose gel (20 mM MOPS and 2.2 M formaldehyde) and visualized under UV light after ethidium bromide staining.

Commercial plant source. A. viridis seed (lot number PM415F; seed harvested in Missouri) was obtained from Prairie Moon Nursery (Winona, MN). Plants from these seed were inoculated 2 weeks post planting with extract from a field sample containing a known Asclepias asymptomatic virus (AsAV) coat protein (CP) sequence to study symptom development, presence of virus, or selection pressure imposed by the host over time.

cDNA synthesis, cloning, and sequence analysis. The $5^{\prime}$ and $3^{\prime}$ terminal sequences of AsAV were determined using primers Tymo5RACE-R (GGTGAGAGTGAGAGGTTCGTGAACTCTG AC) and Tymo3RACE-F (ATGGAAACTGAACGAGTCCTC GTCACCC) and the Smart RACE cDNA amplification kit according to the manufacturer's instructions (Clontech), followed by standard sequencing protocols. The full-length cDNA of the virus was amplified using a $5^{\prime}$ end primer, TymoSalIT3-F, containing an SalI site and T3 RNA promoter sequences and a $3^{\prime}$ end primer, TymoBamHI-R, containing a BamHI site. cDNA was synthesized using $1 \mu \mathrm{g}$ of viral RNA primed with TymoBamHI-R and a Superscript III transcription kit (Invitrogen) at $50^{\circ} \mathrm{C}$. The subsequent PCR reaction was performed with Platinum HiFi Taq (Invitrogen). PCR reaction conditions were $2 \mathrm{~min}$ at $94^{\circ} \mathrm{C}$, followed by 5 cycles under low stringency conditions $\left(20 \mathrm{~s}\right.$ at $94^{\circ} \mathrm{C}$, $30 \mathrm{~s}$ at $55^{\circ} \mathrm{C}$, and $6 \mathrm{~min}$ at $68^{\circ} \mathrm{C}$ ) and 25 cycles under higher stringency conditions $\left(20 \mathrm{~s}\right.$ at $94^{\circ} \mathrm{C}, 30 \mathrm{~s}$ at $64^{\circ} \mathrm{C}$, and $6 \mathrm{~min}$ at $68^{\circ} \mathrm{C}$ ). Reactions were terminated with a 10 -min elongation cycle at $68^{\circ} \mathrm{C}$. Amplified PCR product was cloned into the pGEM T-Easy plasmid vector. A virus consensus sequence was determined by sequencing six independent clones. All the sequencing reactions were performed using the flanking M13 promoter primer in the pGEM T-Easy vector and analyzed in an ABI 3730 capillary sequencer using the BigDye Terminator Sequencing Kit (Applied Biosystems, Foster City, CA). Plasmid containing the full-length clone best representing the consensus sequence of the putative tymovirus was named pAsAV1T3SB.

Phylogenetic analyses. The amino acid sequences of species of Tymoviridae were aligned using the CLUSTAL W algorithm (57) and phylogenic trees were analyzed using MEGA 5 (56). Phylogenetic trees derived from alignment datasets were generated using the neighbor-joining method (49) with a bootstrap test incorporating 1,000 replicates (13) to determine the percentage of replicate trees in which taxa clustered together. Branches with bootstrap values $>50 \%$ are shown. The evolutionary distances were computed using the Poisson correction method (62).

In vitro transcription and plant inoculation. $\mathrm{pAsAV} 1 \mathrm{~T} 3 \mathrm{SB}$ was linearized with $B a m H I$ for run-off transcription and purified with phenol-chloroform. The transcription reaction was per-

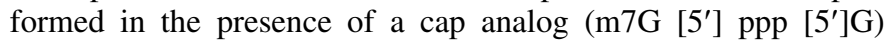
(New England Biolab) using T3 polymerase (Roche) according to the manufacturer's instructions. Synthesized transcripts were directly placed on leaves of 2-week-old $N$. benthamiana plants dusted with carborundum, followed by mechanical abrasion.

Western blot analysis. Two leaf discs per sample from systemically infected leaves were harvested at 15 days postinoculation, ground in $2 \times$ sample loading buffer $(0.5 \mathrm{M}$ Tris- $\mathrm{HCl}$ [pH 6.8], 10\% SDS, 7.5\% glycerol, 5\% $\beta$-mercaptoethanol, and $0.05 \%$ bromophenol blue) and heated in a boiling water bath $\left(100^{\circ} \mathrm{C}\right)$ for $5 \mathrm{~min}$. Proteins were separated by SDS polyacrylamide gel electrophoresis (PAGE). The $\mathrm{CP}$ was detected by a Western blot using a 1:1000 dilution of antiserum against Kennedya yellow mosaic virus (KYMV) purchased from the American Type Culture Collection (accession number PVAS-495; http://www.atcc.org).

Field survey of shoots and caudices of $A$. viridis in 2007 to 2009. The distribution of tymovirus in the TGPP was investigated by taking leaf samples from $\approx 50 \mathrm{~A}$. viridis plants per plot $(151$ plants total) from sampling plots 208 (GPS coordinate east 
728000, north 4078000; zone 14), 307 (GPS coordinate east 731000, north 4079000; zone 14), and 343 (GPS coordinate east 734000, north 4080000; zone 14) in late spring 2007 (35,37). These plots were sampled because they represented a range of possible outcomes for virus presence because single, nonrepetitively sampled $A$. viridis plants bordering each plot in 2005 and 2006 were determined to contain, not contain, or contain in only 1 of the 2 years tymovirus signature sequence. Within each plot, plants were sampled by collecting tissue from the first 12 plants observed when walking from a central coordinate $(0,0)$ position in each cardinal direction (north, south, east, or west). Plants were required to be within $5 \mathrm{~m}$ of one side of each radiating measuring line. Two to three plants were collected from the central coordinate region, a 5-by-5-m square to the northwest of the central coordinate. Individual plants from which samples were collected in 2007 were permanently labeled to allow subsequent harvests from the same plants in following years. Also, samples from A. viridis were taken from two areas $\approx 1.5 \mathrm{~km}$ away from plots 208 or 343 (referred to as 208 remote and 343 remote). For comparison of tymovirus infections within plants between 2007 and 2008, 49 of the 151 plants that were sampled in 2007 were resampled in 2008. The geographical distribution of tymoviruses was further investigated by sampling previously unsampled $A$. viridis plants in the northern, eastern, and southern areas of the TGPP; Foraker, Ponca City, and Tulsa areas outside of the TGPP; and Norman and Lone Grove, OK areas remote from and south of the TGPP in 2008. To determine whether a tymovirus overwintered in A. viridis, 29 caudices of $A$. viridis were collected from tagged plants within plots 208 and 307 in winter 2007-08. In 2009, A. viridis was sampled from both within and just outside of transects encompassing plots 208 and 307. None of these plants had been previously analyzed.

Field sampling, RNA extraction, and RT-PCR. Field samples from aerial portions of plants were obtained using razor blades and consisted of the youngest three to four leaves and associated stem and shoot apical region for each plant. These samples were cut in half in a developmentally consistent manner (i.e., so that each half sample represented the same developmental stages) and were flash frozen in liquid $\mathrm{N}$ at the field site. A new razor blade and gloves were used for each sample to avoid contamination of succeeding samples. For caudex analysis in winter 2007-08, caudices were dug up from shoot locations labeled in 2007. Again, new razor blades and gloves were used for each sampling. Caudex samples were transported to the Noble Foundation on ice and then flash frozen in liquid N. Caudex samples were extracted by grinding subsamples in a mortar and pestle in the presence of liquid N. For both shoot and caudex samples, nucleic acid was extracted and then used for RT-PCR analyses as described in the "Host range analysis" section. To analyze sequence variation between isolates within the $\mathrm{CP} \mathrm{ORF}$, we used primers representing the "tymobox" sequence (GAGKYTGAATTGCTTC), which is shared by most tymoviruses in the $\mathrm{CP}$ promoter region (8), and TGP-Tymo R (ATRGRCGGGGGAGTYGCAC), which is conserved among tymoviruses in their $3^{\prime}$ untranslated region (UTR).

Statistical analyses. We conducted a McNemar test for nonparametric data with correction for continuity (51) to test for significant changes (increases or decreases) in infection of $A$. viridis between 2007 and 2008. The data set included shoot tissue from 49 plants harvested in 2007 ( 25 positive and 24 negative for virus) and then again in 2008 and analyzed for the presence of virus. We also tested for site-specific effects by using two permutation tests-one for gains and one for losses of tymovirus infections-using Matlab (The MathWorks 2007). To conduct each permutation test, we resampled from the original data set for each site with a replacement to create a new data set for that site, keeping the number of observations in each site the same as in the original data set. We performed a permutation test with 5,000 permutations of the data, tested against 5,000 fully randomized data sets. We used the values from the 5,000 permutations from this data set to calculate $95 \%$ confidence limits. If the lower confidence limit of the difference in fractional losses or gains (between data from each site and fully randomized data) was $>0$, then the number of gains or losses in a given site was more than the number of gains and losses among sites. Alternatively, if the upper confidence limit of the difference in fractional losses or gains was $<0$, then the number of gains or losses in a given site was less than the number of gains and losses among sites.

Change in the infection frequency along a north-south gradient was correlated with the ranked latitude for all 13 sites sampled, as described (55). Significance was determined using a permutation test similar to bootstraps as described (10).

To determine whether there was a positive relationship between the particular shoots infected in 2007 and their associated caudices in winter 2008, a binomial test (51) was conducted for the presence or absence of virus in caudices from a population of infected shoots. The sample consisted of 16 infected shoots from 2007.

dN/dS ratios. CP nucleotide sequences representing individual plants were analyzed using SNAP (www.hiv.lanl.gov) (28).

\section{RESULTS}

Host range and symptoms. Previously, it was reported that a high titer of signature sequences for a novel tymovirus existed in A. viridis leaf samples from the TGPP (39). In that report, the tymovirus sequence also was observed in members of the genera Ambrosia, Amorpha, Cephalanthus, and Desmanthus. The presence of the tymovirus sequence was also observed in additional species, both within and outside of these genera, through RT-PCR analysis of extracts from TGPP samples (Fig. 1A) (for Euphorbia: 17). Extract from $A$. viridis containing the virus signature sequence was infectious to $N$. benthamiana, C. amaranticolor, and Datura stramonium but not Arabidopsis thaliana or several members of the family Cucurbitaceae (Fig. 1A and B). Symptoms were extensive on $N$. benthamiana, including chlorosis associated with mottling (Fig. 1C). The extract from one of the infected $N$. benthamiana plants was utilized as a source to clone the fulllength sequence of the putative virus. The location of the $A$. viridis plant within the TGPP used as the source for $N$. benthamiana inoculations and cloning was recorded (see Materials and Methods). There were no severe or reproducibly observable mild disease symptoms observed in any of the $A$. viridis plants containing the tymovirus sequence (compare Fig. 1D and E) (also see images of sampled plants at http://bioinfosu.okstate.edu/ pvbe/index.html). The symptomless nature of the tymovirus in $A$. viridis was verified by mechanically inoculating greenhousegrown virus-free $A$. viridis plants from a commercial source with extracts from a field sample containing the tymovirus signature sequence. Virus sequence was detected in these plants by RTPCR; however, no visible symptoms were apparent, thus supporting the conclusion that this virus is asymptomatic in this host (data not shown).

Virus isolation, physical characterization, and genome organization. Icosahedral capsid-like structures were observed from plants containing the tymovirus signature sequence (Fig. 2A). RNA was extracted from the capsids and a single band of $\approx 6.2 \mathrm{~kb}$ was observed after gel electrophoresis (Fig. 2B). In addition, a single $\approx 19-\mathrm{kDa}$ protein was observed in gels after SDS-PAGE (Fig. 2C). Both the size of the RNA and the single protein are similar to those of tymovirus genomes and their CPs. The putative tymovirus RNA was cloned and comparison of the cDNA sequences with those of known tymovirus members indicated a genome organization and length similar to other tymoviruses (Fig. 2D). It consisted of three ORFs: the first encoding a protein of 634 amino acids (aa). representing the 
69-kDa movement protein (MP); the second encoding a protein of 1,809 aa, representing the 204-kDa RNA-dependent RNA polymerase ( $\mathrm{RdRp})$; and the third encoding a protein of 189 aa, representing the 19-kDa CP. Flanking these ORFs were 72 and 99 nucleotides (nt), respectively, representing the $5^{\prime}$ and $3^{\prime}$ UTRs of the virus. The 16-nt tymobox sequence found within the promoter sequence for the $\mathrm{CP}$ and conserved in most tymoviruses (8) was identified in this virus sequence. Also present was a predicted tRNA-like structure in the 3' UTR of genomic RNA similar to the structure found in TYMV (data not shown) (21). Phylogenetic comparison of the RdRp and CP sequences with other members of the genus Tymovirus indicated that this novel tymovirus was most closely related to KYMV (Fig. 3; RdRp) and multiple members of the tymovirus family, including KYMV (Fig. 3; CP).

Construction of infectious clone and infectivity studies. To characterize a single tymovirus from the isolates within the preserve and provide a reagent for future molecular analysis of this virus, a full-length clone was constructed from which infectious transcript could be produced (Fig. 4). Full-length cDNA $(\approx 6.2 \mathrm{~kb})$ was amplified by RT-PCR with $5^{\prime}$-end upstream and $3^{\prime}$ downstream primers, and the full-length clone was placed behind a T3 promoter and in front of a BamHI restriction site to allow in vitro transcription of an infectious virus sequence (Fig. 4A).
Transcript was rub inoculated onto $N$. benthamiana and disease symptoms observed on 8 of 10 plants (e.g., Fig. 4B). Symptom appearance was delayed 5 days compared with their time of appearance after virion inoculation but the symptoms were identical to those caused by extract from field plants (compare symptoms shown in Figure 4B with those in Figure 1). Progeny virus from plants inoculated with infectious transcript was passaged to healthy $N$. benthamiana, again resulting in identical symptoms (data not shown). Virus accumulation associated with symptom development was confirmed by Western blotting (Fig. 4C). This virus has been tentatively named AsAV. The sequence has been deposited in GenBank (accession number HQ425778). The proposed name will be submitted to the International Committee on Taxonomy of Viruses for evaluation.

Tymovirus distribution over time and space. Considering the significant titer of virus sequence within $A$. viridis extracts and the small sample number of plants that contained the sequence in the initial plant surveys from 2005 and 2006, we considered it necessary to more fully analyze the percentage of $A$. viridis plants infected within the TGPP, the geographical range of the virus in A. viridis, and the spread of the virus over time. In each instance, results were obtained through RT-PCR analysis. To study the geographic distribution of the tymovirus in A. viridis, plants were sampled from three plot locations which contained single

\section{A}

\section{Field samples}

\begin{tabular}{llcc}
\hline Family & Species & Symptom & RT-PCR \\
\hline $\begin{array}{l}\text { Apocynaceae } \\
\text { (tribe: Asclepiadeae) }\end{array}$ & Asclepias viridis & None & + \\
& Asclepias sullivantii & None & + \\
& Asclepias tuberosa & None & - \\
& Cynanchum laeve & None & + \\
$\begin{array}{l}\text { Apocynaceae } \\
\text { (tribe: Apocyneae) }\end{array}$ & Apocynum cannabinum & None & - \\
Poaceae & Panicum virgatum & None & +
\end{tabular}

\section{Experimental hosts}

\begin{tabular}{llcc}
\hline $\begin{array}{l}\text { Chenopodiaceae } \\
\text { Solanaceae }\end{array}$ & $\begin{array}{l}\text { Chenopodium amaranticolor } \\
\text { Nicotiana benthamiana }\end{array}$ & CLL & + \\
& $\begin{array}{l}\text { Nicotiana tabacum cv. } \\
\text { Xanthi-nn }\end{array}$ & None & + \\
& Datura stramonium & None & + \\
Brassicaceae & Arabidopsis thaliana & None & - \\
Cucurbitaceae & Cucurbita pepo & None & - \\
& Cucumis sativus & None & - \\
\hline
\end{tabular}

CLL, chlorotic lesion; CL, chlorosis; M, mosaic; Mo, mottle; None, no symptom; + , positive for tymovirus sequence after reverse transcriptase-polymerase chain reaction (RT-PCR) analysis; -, negative for tymovirus sequence after RT-PCR

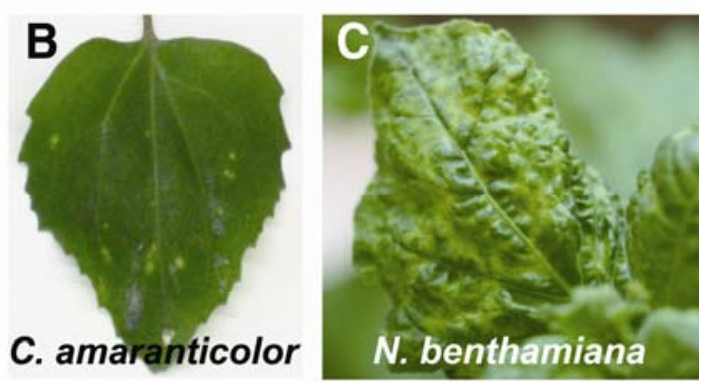

Fig. 1. Range of species with tymovirus sequence and symptoms. A, Visual symptom (Symptom) and presence of tymovirus sequence (reverse-transcription polymerase chain reaction) in plant species obtained from the Tallgrass Prairie Preserve (Field samples) and after inoculation with extract from Asclepias viridis plants containing tymovirus signature sequence (Experimental hosts). B, Visual symptoms induced by tymovirus on $C$. amaranticolor (chlorotic lesions). C, Visual symptoms induced by tymovirus on Nicotiana benthamiana (chlorosis, mottle, mosaic). D, Lack of visual symptoms on A. viridis from field sample containing tymovirus sequence. E, Visual phenotype of A. viridis not containing virus sequence. 
nonidentical plants positive for the tymovirus signature in both 2005 and 2006 (plot 307), positive in 2005 and negative in 2006 (plot 343), or negative both years (plot 208) (Fig. 5A and B). These plots represent a subpopulation of the numerous permanent plots present in every square kilometer of the TGPP for scientific studies (1). In 2007, $\approx 50$ plants were sampled per plot using a transect sampling method (Fig. 5A) (see Materials and Methods for details). A large number of plants from all plots contained the tymovirus sequence (36 to $82 \%$ ) (Fig. $5 \mathrm{~A}$ and B). There was no difference in the percentage of virus infection per transect within plots, with one exception (the west transect of plot 307 had significantly lower infection than the other three transects as determined by $\chi^{2}$ analysis; df $\left.=1, P<0.05\right)$. Thus, there was generally little variation in the geographical distribution of the virus within plots.

Because the permanent plots in the TGPP likely have more human traffic than other areas, there was a possibility that the tymovirus infection could have resulted by mechanical transmission from clothing or other sources on researchers during previous sampling forays (36). To investigate whether the permanent plot areas represented recent focal points for tymovirus invasion, $A$. viridis plants were harvested from areas distant $(\approx 1.5 \mathrm{~km})$ from two of the sampled plots and not within other permanent plots (referred to as remote sites) (Fig. 5). Virus sequence was detected from samples taken from these areas at percentages most closely approximating their nearest permanent plot (Fig. 5). Thus, it seems unlikely that the permanent plots represented recent invasion by the tymovirus due to human activity at the sampled permanent plots.

To further investigate the distribution of tymoviruses both within and outside of the TGPP, A. viridis plants at the north, east, and south edge of the TGPP; west (west of Foraker), southwest (south of Ponca City), and southeast (northwest of Tulsa) of the TGPP; and in central (Norman) and southern (Lone Grove) Oklahoma were collected and analyzed. Virus signature sequence was detected from plants in all these areas, except at the east edge of the TGPP and in central and southern Oklahoma (Fig. 5B).
These results indicate that the tymovirus infection of $A$. viridis extended well beyond the edge of the TGPP but possibly not into central and southern Oklahoma. Regardless of its presence in central or southern Oklahoma, there was a correlation between the fraction of plants infected and the geographic location of the sampled plants. Specifically, the fraction of plants infected in the northern regions was greater than in the southern regions (Spearman rank correlation coefficient $=0.78$ ).

To analyze the spread of virus over time in the sampling plots, plants harvested in 2007 were labeled and sampled again in 2008. New shoots from caudices of both infected and uninfected plants were harvested and analyzed for the tymovirus sequence. We determined that there was a significant increase in the number of infected plants in 2008 (Table 1). There was a strong effect of one site, plot 343 , on the gains of infection as determined through permutation tests $(>95 \%$ of permutations showed that the fraction of plants that became infected in plot 343 was more than the average calculated for all sites combined; Supplementary Table 1). Otherwise, there were no strong effects of site on the frequency of gains or losses of virus by plants in other plots or for losses in plot 343 .

In 2009, plants were sampled within and around transects of plots 208 and 307. These plants had not been sampled in previous years. Tymovirus signature sequence was observed in a higher percentage of plants than in 2007 (Fig. 5B).

Tymovirus sp. overwintering habit. $A$. viridis is a perennial species that produces a new shoot each year from an overwintering underground caudex which may live up to 100 years depending on the Asclepias sp. (59). To determine whether the tymovirus we were studying utilized the caudex to overwinter, 29 caudices were sampled in winter 2007-08 from plants whose shoots were previously analyzed for virus sequence in 2007 (from plants in plots 208 and 307). The majority of plants whose shoots were infected in 2007 contained virus in their caudices (15 of 16; $P<0.05$ of random occurrence) (Table 2). Ten plants contained viruses in their caudices but not their shoots the previous spring. Although it is possible that the previous year's shoot tissue
A

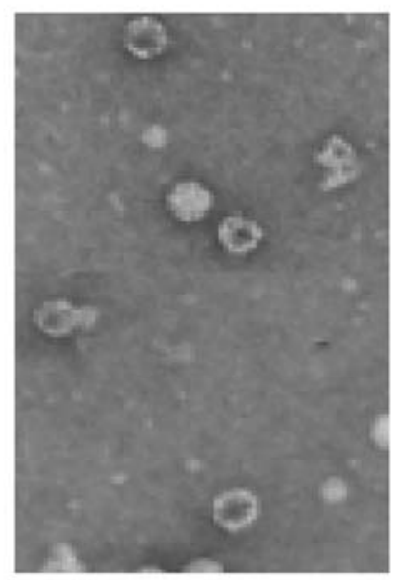

B

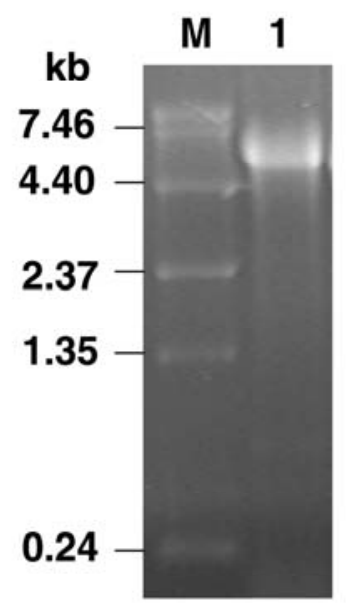

C

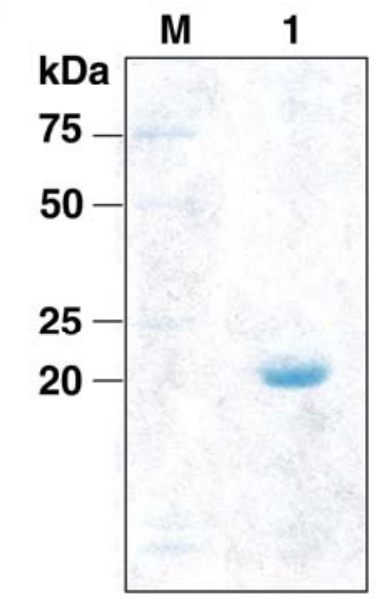

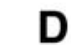

73

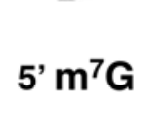

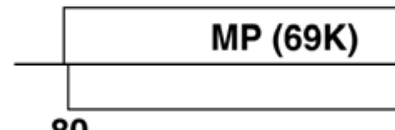

1902

80 RdRp (204K)

Fig. 2. Physical characteristics of tymovirus and schematic of its genome structure. A, Capsid structures observed through electron microscopy from Asclepias viridis leaf sap containing tymovirus signature sequence. Image supplied by Adam Zlotnick. B, Electrophoretic pattern of genomic RNA of tymovirus isolated from capsids in a $0.8 \%$ denaturing agarose gel. Lane M, RNA ladder; lane 1, tymovirus genomic RNA. C, Size of putative coat protein (CP) of tymovirus after gel electrophoresis and staining with Coomassie Brilliant Blue. Lane M, unstained sodium dodecyl sulfate protein size marker; lane 1, purified virus isolated from Nicotiana benthamiana. D, Schematic diagram showing putative open reading frames (ORFs) and untranslated regions for Asclepias asymptomatic virus. $5^{\prime} \mathrm{m}^{7} \mathrm{G}$, $5^{\prime}$ methyl cap for virus RNA; tRNA ${ }^{\text {val }}, 3^{\prime}$ structure in Tymovirus spp. that has tRNA ${ }^{\text {val }}$ mimicry. Numbers indicate nucleotide position of ORFs and end of virus sequence. MP, movement protein; RdRp, RNA-dependent RNA polymerase. 
contained a low but undetectable level of virus, it is also possible that infection of the shoot in 2007 occurred after our spring sampling of shoots but before our winter sampling of each caudex. Because our caudex sampling procedure was destructive, we could not sample new shoot tissue during the 2008 growing season; however, these findings, along with our findings that the vast majority of plants whose shoots were positive in 2007 were also positive in 2008, suggest strongly that the virus overwinters in the caudex.

Tymovirus sequence variation between plants. Because $A$. viridis is long lived, outcrosses to enhance its genetic variability (40), and likely serves as an overwintering host for the virus, we were interested whether the genetically heterologous individual plants imposed unique selection criteria on the virus populations within each plant. We investigated the genetic variability of virus populations between individual plants by sequencing the $\mathrm{CP}$ gene of the virus (567 nt, 189 aa). The nucleotide and amino acid sequences were obtained from 15 plants collected from plots 208 , 307, and 343 of TGPP in 2007. A minimum of three individual clones from each plant were aligned and compared with each other. Nucleotide substitutions within clones representing single plants were less than six for the majority of plants (Table 3, gray boxes). For the other six plants most had 6 to 9 nucleotide substitutions, whereas for plant 12 (plot 208) and plant 25 (plot 307 ), the substitution numbers were 30 and 23 , respectively (average of 6.3 substitutions per $567 \mathrm{nt}$ for all plants). For plants 12 and 25 , several clones had one sequence while the others had an alternative sequence, suggesting that these plants were infected with two related strains of the virus. Unlike the limited number of substitutions observed between sequences from individual clones representing virus from a single plant, substitutions in sequences from different plants consistently were high (averaging 16.8 substitutions per $567 \mathrm{nt}$ ) (Table 4). The nucleotide substitutions between single clones representing each plant are provided to simplify the presentation because comparisons between all clones in all combinations for plants yielded similar results (Tables 3 and 4; data not shown). The nucleotide substitutions were evenly distributed within the CP ORF. There was no influence on the number of nucleotide differences between plants by harvest position either within or between plots (Table 4). Thus, the level nucleotide sequence variation was not influenced by microenvironment (meter based) or macroenvironment (kilometer based) differences in the position between plants.

Although the percentage of nucleotide variation was high in the CP ORF between plants, most were synonymous substitutions resulting in a low $\mathrm{dN} / \mathrm{dS}$ ratio for each plot $(<0.07$ for each plot $)$ (Table 3 ). This finding suggests that the $\mathrm{CP}$ and not its coding sequence is under selection.

To further understand the selection pressure exerted by the host on the virus, nucleotide sequences representing the $\mathrm{CP}$ region from extracts of 10 plants repetitively sampled in 2007 and 2008 were compared. There was no change in the nucleotide sequence within individual plants during the 2-year period (data not shown). We also inoculated healthy $A$. viridis plants from a commercial seed source and analyzed for sequence variation after a 2-month period. Of the nine A. viridis plants inoculated with extract from plant number 26 (plot 343; sample 08TGP343026) which displayed a 3 -nt variation in the individual clones repre-

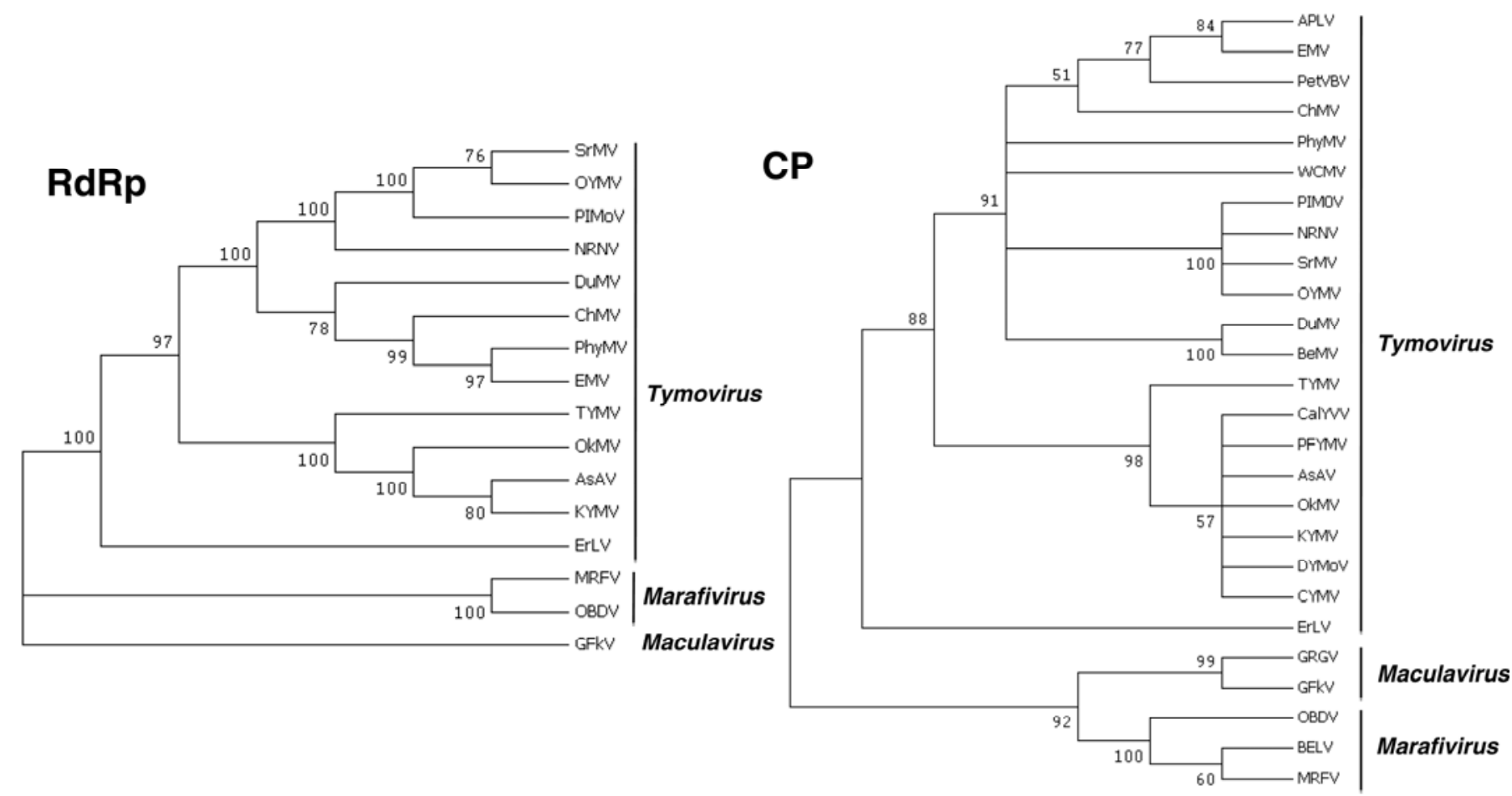

Fig. 3. Phylogenies for Asclepias asymptomatic virus (AsAV) and species in genera from the family Tymoviridae based on amino acid sequences of the RNAdependent RNA polymerase (RdRp) and coat protein (CP). Distance phylogenetic trees were determined by neighbor joining using MEGA5 and the data set was subjected to 1,000 bootstrap repetitions. Bootstrap values $>50 \%$ are shown at the node of branches and branches $<50 \%$ are collapsed. Amino acid sequences of members of the genera Tymovirus, Marafivirus, and Maculavirus were obtained from the protein and nucleic acid sequences in the GenBank database under the following accession numbers: 1, genus Tymovirus: Andean potato latent virus (APLV), AF035402; Belladonna mottle virus (BeMV), X54529; Cacao yellow mosaic virus (CYMV), X54354; Cayote mosaic virus (ChMV), AF195000, Calopogonium yellow mosaic virus (CalYVV), U91314; Chayote mosaic virus (ChMV), AF195000 and NP067738.1; Dulcamara mottle virus (DuMV), NC007609; Desmodium yellow mottle virus (DYMoV), AF035201; Erysimum latent virus (ErLV), NC001977; Eggplant mosaic virus (EMV), NC001480; Kennedya yellow mosaic virus (KYMV), D00637; Nemesia ring necrosis virus (NRNV), YP002308442; Ononis yellow mosaic virus (OYMV), NC001513; Okra mosaic virus (OkMV), NC009532; Plantago mottle virus (PIMoV), AY751779; Physalis mottle virus (PhyMV), NC001513; Passion fruit yellow mosaic virus (PFYMV), AF47107; Petunia vein banding virus (PetVBV), AF210709; Scrophlaria mottle virus (SrMV), AY751777; Turnip yellow mosaic virus (TYMV), NC004063; Wild cucumber mosaic virus (WCMV), AF035633; 2, genus Maculavirus: Grapevine redglobe virus (GRGV), AF521977; Grapevine fleck virus (GFkV), AJ309022; and 3, genus Marafivirus: Maize rayado fino virus (MRFV), U97730; Oat blue dwarf virus (OBDV), U87832; Bermuda grass etched line virus (BELV), AY040531. 
senting the CP ORF, none had new $\mathrm{CP}$ sequence variation compared with the parental source (data not shown). Thus, selection pressure, imposed by the presence of a novel genetic background, did not result in rapid nucleotide sequence alterations.

\section{DISCUSSION}

Previous reports on tymoviruses often focused on the identification and, in some cases, cloning of novel representatives from native plants $(2,44,52)$, their ecology $(2,20,52)$, or their epidemiology $(20,54)$ but not all of these attributes at once for a single novel representative. In this study, we addressed, to some extent, all of these areas to further characterize a novel tymovirus that infects A. viridis in the TGPP of northeastern Oklahoma, within the United States. With these findings, we can better assess the potential for this virus to infect other species in Oklahoma and the region. We have established baseline data necessary for future studies on how the virus may influence $A$. viridis development and fecundity. In addition, the production of an infectious clone allows for future identification of host range determinants within the virus genome and its potential application as a vector in studies of gene function in Asclepias spp. through RNA silencing.

AsAV host range and disease development. In our host range analysis for this virus (Fig. 1), it was interesting to find the sequence in Panicum virgatum, a grass species native to the region and currently under consideration as a crop species for biofuel production (61). Tymoviruses previously have not been associated with grasses $(16,34)$. The percentage of AsAV sequence from the total sequences obtained from extracts of capsids within $P$. virgatum was low (39). In addition, the band intensity present after RT-PCR analysis was weak (B. Min and R. Nelson, unpublished). Attempts to passage the virus from $P$. virgatum to $N$. benthamiana failed (B. Min and R. Nelson, unpublished). It is possible that AsAV is poorly adapted to $P$. virgatum, resulting in poor accumulation within this plant. However, the presence of AsAV sequence in this species and not some other grass species from the TGPP indicates a greater potential for it to further adapt to $P$. virgatum. Further opportunity to adapt to $P$. virgatum could occur if this species is grown in monoculture for biofuels production $(31,38)$. Such adaptation could range from antagonistic to beneficial for the host (47). The full host range of this virus will be more apparent from deep sequencing of plant extracts (48).

Viruses have diverged within native plants for millions of years, which may lead to reduced virulence or increased tolerance of viruses and modest disease symptoms $(7,14,31)$. The lack of symptoms induced by AsAV on $A$. viridis supports a long-term virus-host interaction between these species. However, A. viridis may not be the original or only adapted host because other plant species in the TGPP (Cynanchum laeve and A. sullivantii) infected with the virus also displayed no symptoms (Fig. 1). It will be interesting to know whether this virus causes symptoms on any TGPP species, perhaps indicating a recent jump to a new host species.

A

(TymoSallT3-F) Sall T3 Promoter viral sequence

5' - GAGAGGTCGACAATTAACCCTCACTAAAGGTAATCTTTACCGAACAGT - 3 ,

in vitro transcription

5' Sall T3

BamHI

\section{3' - GATAAGGCCTGCAGTGGCCTTGGTCCTAGGAG - 5' viral sequence BamH I (TymoBamHI-R)}
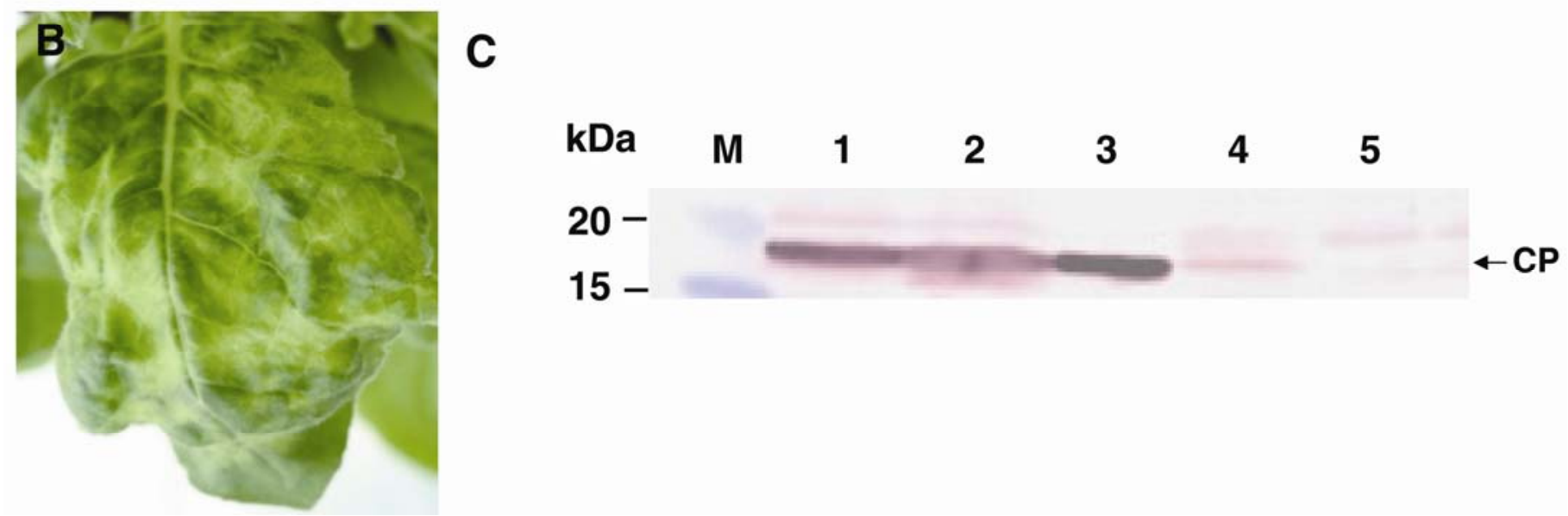

Fig. 4. Production of an infectious clone of Asclepias asymptomatic virus (AsAV) and analysis of progeny virus. A, Schematic representation of the promoter and restriction site elements present for the production of infectious transcript of AsAV. Open box; AsAV genome. Transcription begins at first G of the viral sequence (terminal "G" of T3 promoter). Image is not to scale. B, Symptom on systemically infected leaf of Nicotiana benthamiana after inoculation with infectious transcript of AsAV. C, Detection of coat protein (CP) from plants inoculated with infectious transcript or crude extract containing AsAV. Plant extract from leaves of $N$. benthamiana and Asclepias viridis were probed with antibody against the capsid of Kennedya yellow mottle virus (KYMV) which cross-reacts with the CP of AsAV. Lane M, prestained sodium dodecyl sulfate protein size marker; lane 1, extract from systemically infected leaf of transcript-inoculated $N$. benthamiana; lane 2, extract from systemically infected leaf of AsAV-infected $N$. benthamiana; lane 3,1 $\mu$ g of purified virus isolated from AsAV-infected $N$. benthamiana; lane 4, extract from systemically infected leaf of AsAV-infected A. viridis; lane 5, extract from upper leaf of mock-inoculated N. benthamiana. Arrow indicates the position of CP. 
AsAV distribution, spread over time, and overwintering character in A. viridis. The presence of AsAV in a large population of plants throughout the TGPP and northeast Oklahoma suggests that the infection in this region has existed for a long period of time (Fig. 5). Although there is a higher percentage of infection in the northern portion of the sampled region compared with the southern region, there is not enough information to determine where this particular infection originated. The ability of the virus to reside in the caudex of the overwintering plant (Table 2) and the repetitive appearance of the virus in shoots from individual caudices in successive growing seasons (Table 1) supports the conclusion that this virus-host system would yield a geographically wide-ranging uniform infection pattern because the virus would always be present in currently infected regions and could spread to new virus-free seedlings. This spreading phenomenon was apparent in our repetitive sampling of plants between 2007 and 2008 (Table 1). It was interesting that the increase in infected plants was due to increased infections in plot 343, the plot with the highest percentage of infection in 2007 $(82 \%)$. Tymoviruses are often vectored by beetles and it is possible that the insect vector population in this area was greater than in the southwest region. Tetraopes spp. (red milkweed beetle), which generally are restricted to feeding on Asclepias spp. (12), were observed on the $A$. viridis plants and extracts from sampled beetles did contain AsAV sequences (A. Ali, B. Min, and R. S. Nelson, unpublished data). A second explanation for the more extensive spread within the most infected plot is that the high percentage of infection in this plot led to a greater likelihood of local spread of the virus into the remaining uninfected plants, regardless of the insect density. Further research on the population density and ability of Tetraopes spp. to vector AsAV will help to further understand the epidemiology of this virus.

The ability of viruses to survive through dormant growth periods in storage tissue (i.e., caudices of $A$. viridis for this tymovirus) (Table 2) is not uncommon among plant viruses. Cucumber mosaic virus and BBWV survive in overwintering structures of

TABLE 1. Tymovirus spread over time in 49 Asclepias viridis plants sampled from three plots in the Tallgrass Prairie Preserve in 2007 and 2008

\begin{tabular}{lccc}
\hline & \multicolumn{2}{c}{ Tymovirus presence } \\
in 2008 & \\
\cline { 2 - 3 } Tymovirus presence in 2007 & Negative & Positive & Total for 2007 \\
\hline Negative & 15 & 10 & 25 \\
Positive & 2 & 22 & $24^{\mathrm{a}}$ \\
Totals for 2008 & 17 & $32^{\mathrm{a}}$ & $\ldots$ \\
\hline
\end{tabular}

${ }^{a}$ Increase in infected plants from 2007 (24) to 2008 (32) significant at the $P=0.05$ level.

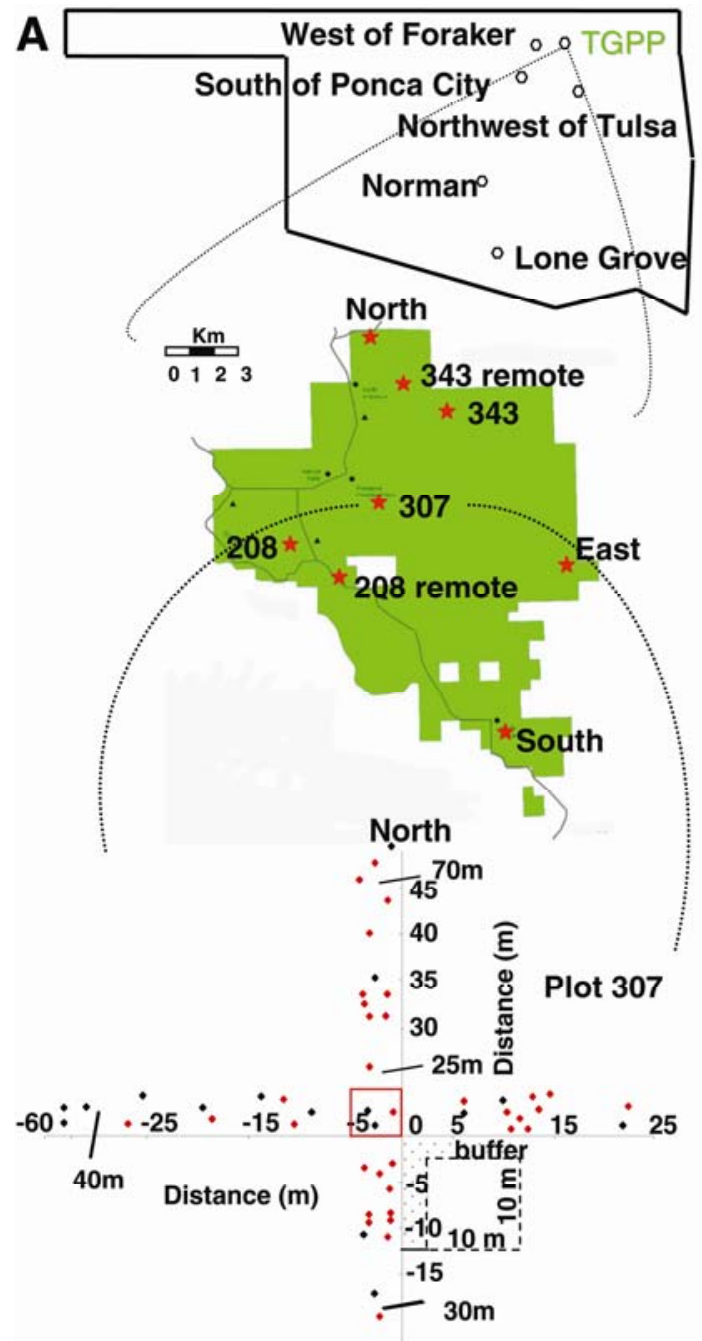

\begin{tabular}{|c|c|c|c|c|c|}
\hline \multirow[t]{2}{*}{ Location } & \multicolumn{4}{|c|}{$\begin{array}{c}\text { Presence of AsAV } \\
\text { over time in TGPP and in other regions in } \\
\text { Oklahoma }\end{array}$} & \multirow[b]{2}{*}{2009} \\
\hline & 2005 & 2006 & 2007 & 2008 & \\
\hline Plot 208 & $-a$ & - & $\underset{(36 \%, 18 / 50)^{\mathrm{b}}}{+}$ & + & $\stackrel{+}{+}$ \\
\hline Plot 307 & + & + & $\stackrel{+}{+}$ & + & $\stackrel{+}{+}$ \\
\hline Plot 343 & + & - & $(82 \%, \stackrel{+}{42 / 51)}$ & + & ND \\
\hline 208 remote & ND & ND & $\stackrel{+}{+}$ & ND & ND \\
\hline 343 remote & ND & ND & $\stackrel{+}{+}$ & ND & ND \\
\hline South & ND & ND & ND & $\stackrel{+}{+}$ & ND \\
\hline North & ND & ND & ND & $\stackrel{+}{+}$ & ND \\
\hline East & ND & ND & ND & $(0 \%, 0 / 10)$ & ND \\
\hline $\begin{array}{l}\text { Ponca City } \\
\text { (southwest) }\end{array}$ & ND & ND & ND & $\stackrel{+}{+}$ & ND \\
\hline $\begin{array}{c}\text { Tulsa } \\
\text { (southeast) }\end{array}$ & ND & ND & ND & $\stackrel{+}{+}$ & ND \\
\hline $\begin{array}{l}\text { Foraker } \\
\text { (west) }\end{array}$ & ND & ND & ND & $\stackrel{+}{+}$ & ND \\
\hline Norman & ND & ND & ND & $(0 \%, 0 / 10)$ & ND \\
\hline Lone Grove & ND & ND & ND & $(0 \%, 0 / 10)$ & ND \\
\hline
\end{tabular}

a ; -, virus sequence absent; +, virus sequence present; ND, not determined.

b; values in parentheses represent the \% of plants with virus sequence followed by the number of plants with virus sequence over the total number of plants analyzed.

Fig. 5. Presence of Asclepias asymptomatic virus (AsAV) in Asclepias viridis over time and space in Oklahoma. A. viridis plants were sampled through a 5-year period to determine the location of AsAV within Oklahoma and its persistence within the Tallgrass Prairie Preserve (TGPP). A, Map of region where A. viridis was sampled (green area is TGPP property) and schematic of representative plot 307 and its transects, from the three harvested over time in the TGPP. Red dots, infected plants in 2007; black dots, uninfected plants in 2007; red square, central coordinate region; dashed square, permanent sampling plot; buffer, $5 \mathrm{~m}$ zone between permanent plot and sampling region. B, Analysis for virus through years and among different locations within the TGPP and Oklahoma. 
perennial or biperennial weed hosts (43) and Wild potato mosaic virus, which infects wild potato plants that grow during winter, persists through the dry summer period in dormant tubers underground (26).

Sequence variation between plants. The presence of significantly greater AsAV nucleotide sequence variation within the $\mathrm{CP}$

TABLE 2. Presence of tymovirus in shoot and caudex of individual plants over time ${ }^{\mathrm{a}}$

\begin{tabular}{|c|c|}
\hline Plant number & 2007 shoot (spring)/2008 caudex (winter) \\
\hline \multicolumn{2}{|l|}{ Plot 208} \\
\hline 1 & $-1-$ \\
\hline 21 & $-1+$ \\
\hline 3 & $+/+$ \\
\hline 8 & $+/+$ \\
\hline 9 & $-1+$ \\
\hline 11 & $+/+$ \\
\hline 22 & $+/+$ \\
\hline 23 & $-1+$ \\
\hline 24 & $+/+$ \\
\hline 27 & $-1+$ \\
\hline 33 & $+1-$ \\
\hline 35 & $+/+$ \\
\hline 42 & $-1-$ \\
\hline 43 & $-1-$ \\
\hline 47 & $+/+$ \\
\hline 48 & $+/+$ \\
\hline \multicolumn{2}{|l|}{ Plot 307} \\
\hline 3 & $-1+$ \\
\hline 4 & $+/+$ \\
\hline 6 & $-1+$ \\
\hline 8 & $-1+$ \\
\hline 16 & $-1+$ \\
\hline 17 & $+/+$ \\
\hline 20 & $+/+$ \\
\hline 28 & $+/+$ \\
\hline 29 & $+/+$ \\
\hline 33 & $-1+$ \\
\hline 34 & $+/+$ \\
\hline 35 & $-1+$ \\
\hline 38 & $+/+$ \\
\hline
\end{tabular}

a Season indicates when shoots or caudices were collected; - and + indicate negative or positive, respectively, for tymovirus by reverse-transcription polymerase chain reaction.
ORF between plants versus within plants (Table 3 ) may reflect the AsAV-A. viridis ecological relationship; namely, that the host is long lived and genetically diverse due to outcrossing, and the virus can survive throughout the life of the plant by overwintering in its caudex. However, the influence of each of these characteristics on the sequence variation may not be equal (i.e., does the long-lived nature of the plant and the ability of the virus to survive through seasons allow slow genetic drift or does the plant's outcrossing capacity result in selection pressure within individual plants driving rapid unique sequence divergence of the virus within these individuals?). We approached the issue of selection and sequence divergence by inoculating greenhousegrown $A$. viridis plants from a novel source and genotype (i.e., a commercial seed source whose seed were harvested in Missouri). The absence of nucleotide sequence variation from the parental sequence 2 months after inoculation (see Results) supported the view that the sequence variation was under weak or no selection and, perhaps, represented genetic drift. No variation was observed over time in sequences from the same plants in 2007 and 2008, further supporting genetic drift as the cause of the variation because it usually occurs more slowly than directed modifications. The general lack of nonsynonymous nucleotide substitutions within the virus sequence further supported the genetic drift theory (Table 3 ). The CP of tymoviruses is involved in local and systemic spread of the virus $(4,32,53,54)$, and, thus, is likely

TABLE 4. Nucleotide differences within the coat protein (CP) gene of a tymovirus between plants harvested within or between three plots of the Tallgrass Prairie Preserve in 2007

\begin{tabular}{lccc}
\hline & \multicolumn{4}{c}{$\begin{array}{c}\text { Nucleotide differences within the CP } \\
\text { open reading frame among isolates }\end{array}$} \\
\cline { 2 - 4 } Location $^{\mathrm{b}}$ & Plot $208(5)$ & Plot $307(5)$ & Plot 343 (5) \\
\hline Plot 208 & $15.8 \pm 4.3^{\mathrm{c}}$ & $19.2 \pm 7.8$ & $16.4 \pm 4.4$ \\
Plot 307 & $\ldots$ & $17.6 \pm 5.6$ & $16.1 \pm 3.4$ \\
Plot 343 & $\ldots$ & $\ldots$ & $13.8 \pm 4.6$ \\
\hline
\end{tabular}

${ }^{a}$ Harvest location.

b Number in parentheses = number of plants compared; one isolate per plant.

${ }^{c} \mathrm{X} \pm \mathrm{Y}=$ mean \pm standard deviation of nucleotide differences in $\mathrm{CP}$ sequence between all isolates within or between nucleotide differences between all isolates regardless of location $=16.8 \pm 5.4$.

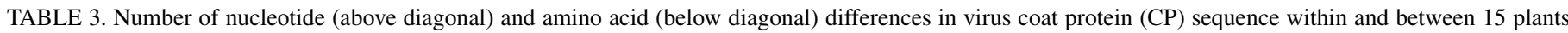
from three field plots harvested from the Tallgrass Prairie Preserve in $2007^{\mathrm{a}}$

\begin{tabular}{|c|c|c|c|c|c|c|c|c|c|c|c|c|c|c|c|}
\hline \multirow[b]{3}{*}{ Location, plant } & \multicolumn{15}{|c|}{ Plant number ${ }^{b}$} \\
\hline & \multicolumn{5}{|c|}{ Plot 208} & \multicolumn{5}{|c|}{ Plot 307} & \multicolumn{5}{|c|}{ Plot 343} \\
\hline & $6(4)$ & $11(4)$ & $12(3)$ & $19(4)$ & $40(4)$ & $14(3)$ & $25(4)$ & $36(4)$ & $38(3)$ & $46(4)$ & $3(4)$ & $12(3)$ & $26(3)$ & $36(3)$ & $44(4)$ \\
\hline \multicolumn{16}{|l|}{ Plot 208} \\
\hline 6 & 1 & 24 & 15 & 19 & 9 & 17 & 30 & 19 & 16 & 16 & 19 & 17 & 13 & 20 & 15 \\
\hline 11 & 1 & 2 & 16 & 17 & 20 & 23 & 33 & 27 & 24 & 19 & 25 & 19 & 21 & 25 & 23 \\
\hline 12 & 1 & 0 & 30 & 12 & 10 & 12 & 24 & 14 & 10 & 5 & 14 & 6 & 11 & 13 & 14 \\
\hline 19 & 2 & 1 & 1 & 0 & 16 & 16 & 23 & 19 & 17 & 11 & 18 & 14 & 16 & 20 & 18 \\
\hline 40 & 1 & 0 & 0 & 1 & 6 & 40 & 27 & 14 & 15 & 9 & 14 & 12 & 12 & 17 & 14 \\
\hline \multicolumn{16}{|l|}{ Plot 307} \\
\hline 14 & 1 & 0 & 0 & 0 & 0 & 2 & 18 & 10 & 15 & 13 & 15 & 14 & 12 & 16 & 14 \\
\hline 25 & 3 & 1 & 2 & 2 & 1 & 1 & 23 & 21 & 29 & 25 & 19 & 21 & 18 & 24 & 19 \\
\hline 36 & 1 & 0 & 0 & 1 & 0 & 0 & 1 & 1 & 18 & 12 & 20 & 17 & 18 & 19 & 18 \\
\hline 38 & 1 & 0 & 0 & 1 & 0 & 0 & 1 & 0 & 1 & 15 & 19 & 13 & 15 & 16 & 17 \\
\hline 46 & 1 & 0 & 0 & 1 & 0 & 0 & 1 & 0 & 0 & 1 & 13 & 9 & 11 & 13 & 13 \\
\hline \multicolumn{16}{|l|}{ Plot 343} \\
\hline 3 & 1 & 0 & 0 & 1 & 0 & 0 & 1 & 0 & 0 & 0 & 3 & 19 & 8 & 20 & 8 \\
\hline 12 & 1 & 0 & 0 & 1 & 0 & 0 & 1 & 0 & 0 & 0 & 1 & 6 & 14 & 16 & 17 \\
\hline 26 & 1 & 0 & 0 & 1 & 0 & 0 & 1 & 0 & 0 & 0 & 1 & 0 & 3 & 14 & 6 \\
\hline 36 & 1 & 0 & 0 & 1 & 0 & 0 & 1 & 0 & 0 & 0 & 2 & 1 & 1 & 7 & 16 \\
\hline 44 & 2 & 1 & 1 & 2 & 1 & 1 & 2 & 1 & 1 & 1 & 1 & 0 & 0 & 1 & 9 \\
\hline
\end{tabular}

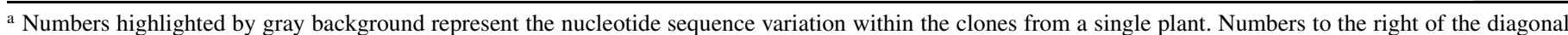
or left of the diagonal represent the nucleotide and amino acid sequence variation, respectively, between single representative clones between plants. $\mathrm{dN} / \mathrm{dS}$ ratios for single representative clones for each plant within plots are 0.03, plot 208; 0.04, plot 307; and 0.06, plot 343 .

b Number in parenthesis is the number of independent $\mathrm{CP}$ clones sequenced from that plant. 
under selection. Thus, if cis-acting elements were present in the viral RNA and were under similar selection pressure to that influencing the CP itself, a similar level of selection would be expected to occur at the nucleotide level.

Interestingly, a similar level of sequence variation within the $\mathrm{CP}$ coding region of another tymovirus, TYMV, was observed between plants of the perennial Cardamine robusta in Australia (20). Considerably more nonsynonymous substitutions were observed in the CP nucleotide sequence of TYMV compared with AsAV but they were still less than would be expected if $\mathrm{CP}$ and $\mathrm{CP}$ nucleotide sequences were under similar selection pressure. These results suggest that this virus-host combination, like AsAV-A. viridis, is also under differential selection for its $\mathrm{CP}$ nucleotide encoding sequence and the $\mathrm{CP}$ itself. However, those authors did observe that there were no nucleotide substitutions in the $180 \mathrm{nt}$ at the $3^{\prime}$ terminal region of the CP ORF for TYMV (20). For AsAV, the nucleotide modifications appeared evenly throughout the CP ORF (data not shown). These findings suggest that, unlike TYMV, AsAV did not have a cis-acting 3' portion of the CP ORF that was under selection. It will be interesting to compare the secondary and tertiary structures of these RNA sequences to determine whether differences exist that can be correlated with function.

\section{ACKNOWLEDGMENTS}

B.-E. Min and T. S. Feldman contributed equally to this article. This work was supported by National Science Foundation-EPSCoR award EPS-0447262 and the Noble Foundation. We thank V. Thapa, G Shen, and V. Grover for help in sampling plants and taking pictures at the TGPP; A. Zlotnick for the image of the AsAV capsid; P. Earls who, through the years, was critical in providing support in finding sampling plots, identifying plants, and sampling tissue; B. Hamilton, whose support of the project was essential to allow access to the TGPP; F. Coker and V. Barrett for greenhouse support; Y. Song for database management and sequencing; and S. R. Uppalapati and M. Udvardi for critically reviewing the manuscript.

\section{LITERATURE CITED}

1. Allen, M. S., Hamilton, R. G., Melcher, U., and Palmer, M. W. 2009. Lessons from the prairie: Research at The Nature Conservancy's Tallgrass Prairie Preserve. Okla. Acad. Sci., Stillwater, OK.

2. Bernal, J. J., Jiménez, I., Moreno, M., Hord, M., Rivera, C., Koenig, R., and Rodríguez-Cerezo, E. 2000. Chayote mosaic virus, a new tymovirus infecting cucurbitaceae. Phytopathology 90:1098-1104.

3. Borer, E. T., Hosseini, P. R., Seabloom, E. W., and Dobson, A. P. 2007. Pathogen-induced reversal of native dominance in a grassland community. Proc. Natl. Acad. Sci. USA 104:5473-5478.

4. Bransom, K. L., Weiland, J. J., Tsai, C. H., and Dreher, T. W. 1995. Coding density of the turnip yellow mosaic virus genome: Roles of the overlapping coat protein and p206-readthrough coding regions. Virology 206:403-412

5. Brunt, A., Crabtree, K., Dallwitz, M., Gibbs, A., and Watson, L. 1996. Viruses of Plants. CAB International, Wallingford, UK.

6. Chapman, S. N. 1998. Tobamovirus isolation and RNA extraction. In: Plant Virology Protocols. G. D. Forster, and S. C. Taylor, eds. Humana Press, Totowa, NJ.

7. Cooper, I., and Jones, R. A. 2006. Wild plants and viruses: Underinvestigated ecosystems. Adv. Virus Res. 67:1-47.

8. Ding, S. W., Howe, J., Keese, P., Mackenzie, A., Meek, D., Osorio-Keese, M., Skotnicki, M., Srifah, P., Torronen, M., and Gibbs, A. 1990. The tymobox, a sequence shared by most tymoviruses: Its use in molecular studies of tymoviruses. Nucleic Acids Res. 18:1181-1187.

9. Ding, S., Keese, P., and Gibbs, A. 1990. The nucleotide sequence of the genomic RNA of kennedya yellow mosaic tymovirus-Jervis Bay isolate: Relationships with potex- and carlaviruses. J. Gen. Virol. 71: 925-931.

10. Dixon P. M. 2001. The Bootstrap and the Jackknife: Describing the precision of ecological indices. Pages 267-288 in: The Design and Analysis of Ecological Experiments. S. M. Scheiner and J. Gurevitch, eds. Chapman \& Hall, New York.

11. Elena, S. 2011. Evolutionary constraints on emergence of plant RNA viruses. Pages 283-300 in: Recent Advances in Plant Virology. C. Caranta,
M. A. Aranda, M. Tepfer, and J. J. López-Moya, eds. Caister Academic Press, Norfolk, UK.

12. Farrell, B. D., and Mitter, C. 1998. The timing of insect/plant diversification: Might Tetropes (Coleoptera: Cerambycidae) and Asclepias (Asclepiadacea) have co-evolved? Biol. J. Linn. Soc. 63:553-577.

13. Felsenstein, J. 1985. Confidence limits on phylogenies: An approach using the bootstrap. Evolution 39:783-791.

14. García-Arenal, F., and Fraile, A. 2008. Questions and concepts in plant virus evolution: A historical perspective. Pages 1-14 in: Plant Virus Evolution. M. J. Roossinck, ed. Springer-Verlag, Berlin, Heidelberg, Germany.

15. Gibbs, A. J., Keese, P. L., Gibbs, M. J., and Garcia-Arenal, F. 1999. Plant virus evolution: Past, present and future. Pages 263-285 in: Origin and Evolution of Viruses. E. Domingo, R. Webster, and J. Holland, eds. Academic Press, San Diego, CA.

16. Gibbs, A., and Mackenzie, A. M. 1998. Tymovirus isolation and genomic RNA extraction. Methods Mol. Biol. 81:219-224.

17. Hackett, J., Muthukumar, V., Wiley, G. B., Roe, B. A., and Melcher, U. 2009. Viruses in Oklahoma Euphorbia marginata (Pursh). Proc. Okla. Acad. Sci. 89:57-62.

18. Hamilton, R. G. 2007. Restoring heterogeneity on the Tallgrass Prairie Preserve: Applying the fire-grazing interaction model. Pages 163-169 in: Proc. 23rd Tall Timbers Fire Ecol. Conf.: Fire in Grassland and Shrubland Ecosystems. R. E. Masters and K. E. M. Galley, eds. Tall Timbers Research Station, Tallahassee, FL.

19. Harrison, B. D. 1981. Plant virus ecology: Ingredients, interactions and environment influences. Ann. Appl. Biol. 99:195-209.

20. Hayden, C. M., Mackenzie, A. M., and Gibbs, A. J. 1998. Virion protein sequence variation among Australian isolates of turnip yellow mosaic tymovirus. Arch. Virol. 143:191-201.

21. Hellendoorn, K., Mat, A. W., Gultyaev, A. P., and Pleij, C. W. 1996. Secondary structure model of the coat protein gene of turnip yellow mosaic virus RNA: Long, C-rich, single-stranded regions. Virology 224:43-54.

22. Hull, R. 2002. Matthews' Plant Virology. Academic Press, San Diego, CA.

23. Jaaskelainen, A. J., and Maunula, L. 2006. Applicability of microarray technique for the detection of noro- and astroviruses. J. Virol. Methods 136:210-216.

24. Jones, R. A. 2009. Plant virus emergence and evolution: Origins, new encounter scenarios, factors driving emergence, effects of changing world conditions, and prospects for control. Virus Res. 141:113-130.

25. Jones, R. A. C., and Fribourg, C. E. 1977. Beetle, contact and potato true seed transmission of Andean potato latent virus. Ann. Appl. Biol. 86: 123-128.

26. Jones, R. A. C., and Fribourg, C. E. 1979. Host plant reactions, some properties, and serology of Peru tomato virus. Phytopathology 69:446449.

27. Keese, P., Mackenzie, A., and Gibbs, A. 1989. Nucleotide sequence of the genome of an Australian isolate of turnip yellow mosaic tymovirus. Virology 172:536-546.

28. Korber, B. 2000. HIV signature and sequence variation analysis. Chapter 4, pages 55-72 in: Computational Analysis of HIV Molecular Sequences. A. G. Rodrigo and G. H. Learn, eds. Kluwer Academic Publishers, Dordrecht, The Netherlands.

29. Lartey, R. T., Voss, T. C., and Melcher, U.. 1996. Tobamovirus evolution: Gene overlaps, recombination, and taxonomic implications. Mol. Biol. Evol. 13:1327-1338.

30. Logemann, J., Schell, J., and Willmitzer, L. 1987. Improved method for the isolation of RNA from plant tissues. Anal. Biochem. 163:16-20.

31. Lovisolo, O., Hull, R., and Rosler, O. 2003. Coevolution of viruses with hosts and vectors and possible paleontology. Adv. Virus Res. 62:325-379.

32. Maccheroni, W., Alegria, M. C., Greggio, C. C., Piazza, J. P., Kamla, R. F., Zacharias, P. R. A., Bar-Joseph, M., Kitajima, E. W., Assumpcão, R. C., Camarotte, G., Cardozo, J., Casagrande, E. C., Ferrari, F., Franco, S. F., Giachetto, P. F., Girasol, A., Jordão, H., Jr., Silva, V. H. A., Souza, L. C. A., Aguilar-Vildoso, C. I., Zanca, A. S., Arruda, P., Kitajima, J. P., Reinach, F. C., Ferro, J. A., and Silva, A. C. R. 2005. Identification and genomic characterization of a new virus (Tymoviridae Family) associated with Citrus Sudden Death disease. J. Virol. 79:3028-3037.

33. Malmstrom, C. M., Shu, R., Linton, E. W., Newton, L. A., and Cook,. M. A. 2007. Barley yellow dwarf viruses (BYDVs) preserved in herbarium specimens illuminate historical disease ecology of invasive and native grasses. J. Ecol. 95:1153-1166.

34. Martelli, G. P., Sabanadzovic, S., Abou-Ghanem Sabanadzovic, N., Edwards, M. C., and Dreher, T. 2002. The family Tymoviridae. Arch. Virol. 147:1837-1846.

35. McGlinn, D. J., Earls, P. G., and Palmer M. W. 2010. A twelve-year study on the scaling of vascular plant composition in an Oklahoma tallgrass prairie. Ecology 91:1872.

36. McKinney, H. H. 1953. New evidence on virus diseases in barley. Plant Dis. Rep. 37:292-295. 
37. Melcher, U., Muthukumar, V., Wiley, G. B., Min, B. E., Palmer, M. W., Verchot-Lubicz, J., Ali, A., Nelson, R. S., Roe, B. A., Thapa, V., and Pierce, M. L. 2008. Evidence for novel viruses by analysis of nucleic acids in virus-like particle fractions from Ambrosia psilostachya. J. Virol. Methods 152:49-55.

38. Mundt, C. C. 2002. Use of multiline cultivars and cultivar mixtures for disease management. Annu. Rev. Phytopathol. 40:381-410.

39. Muthukumar, V., Melcher, U., Pierce, M., Wiley, G. B., Roe, B., Palmer, M. W., Thapa, V., Ali, A., and Ding, T. 2009. Non-cultivated plants of the Tallgrass Prairie Preserve of northeastern Oklahoma frequently contain virus-like sequences in particulate fractions. Virus Res. 141:169-173.

40. Neyland, R., Hoffman, R., Meyer, B. J., and Lowenfeld, H. A. 1999. Initial investigation into the reproductive biology of the antelope-horn milkweed, Asclepias viridis Walter (Asclepiadaceae). Proc. La. Acad. Sci. 28.

41. Palmer, M. W. 2006. The vascular flora of the Tallgrass Prairie Preserve, Osage County, Oklahoma. Castanea 72:235-246.

42. Raybould, A. F., Maskell, L. C., Edwards, M. L., Cooper, J. I., and Gray, A. J. 1999. The prevalence and spatial distribution of viruses in natural populations of Brassica oleracea. New Phytol. 141:265-275.

43. Rist, D. L., and Lorbeer, J. W. 1989. Occurrence and overwintering of cucumber mosaic virus and broad bean wilt virus in weeds growing near commercial lettuce fields in New York. Phytopathology 79:65-69.

44. Robertson, N. L. 2007. A new tymovirus from a native Alaskan plant, Mertensia paniculata. (Abstr.) Phytopathology 97:S100.

45. Rojas, M. R., and Gilbertson, R. L. 2008. Emerging plant viruses: A diversity of mechanisms and opportunities. Pages 27-51 in: Plant Virus Evolution. M. J. Roossinck, ed. Springer-Verlag, Berlin Heidelberg, Germany.

46. Roossinck, M. J. 2005. Symbiosis versus competition in plant virus evolution. Nat. Rev. Microbiol. 3:917-924.

47. Roossinck, M. J. 2008. Symbiosis, mutualism and symbiogenesis. Pages 157-164 in: Plant Virus Evolution. M. J. Roossinck, ed. Springer-Verlag, Berlin, Heidelberg, Germany.

48. Roossinck, M. J., Saha, P., Wiley, G. B., Quan, J., White, J. D., Lai, H., Chavarría, F., Shen, G., and Roe, B. A. 2010. Ecogenomics: Using massively parallel pyrosequencing to understand virus ecology. Mol. Ecol. 19:81-88.

49. Saitou, N., and Nei, M. 1987. The neighbor-joining method: A new method for reconstructing phylogenetic trees. Mol. Biol. Evol. 4:406-425.
50. Scheets, K., Blinkova, O., Melcher, U., Palmer, M. W., Wiley G. B., Ding, T., and Roe, B. A. 2011. Detection of members of the Tombusviridae in the Tallgrass Prairie Preserve, Osage County, Oklahoma, USA. Virus Res. 160:256-263.

51. Siegel, S. 1956. Nonparametric Statistics for the Behavioral Sciences. McGraw-Hill Book Co., New York.

52. Skelton, A. L., Jarvis, B., Koenig, R., Lesemann, D.-E., and Mumford, R. A. 2004. The isolation and identification of a tymovirus from Nemesia in the UK. Plant Pathol. 53:798.

53. Skotnicki, M. L., Mackenzie, A. M., Ding, S. W., Mo, J. Q., and Gibbs, A. J. 1993. RNA hybrid mismatch polymorphisms in Australian populations of turnip yellow mosaic tymovirus. Arch. Virol. 132:83-99.

54. Skotnicki, M. L., Mackenzie, A. M., and Gibbs, A. J. 1996. Genetic variation in populations of kennedya yellow mosaic tymovirus. Arch. Virol. 141:99-110.

55. Sokal, R. R., and Rohlf, F. J. 1995. Biometry: The Principles and Practice of Statistics in Biological Research, 3rd ed. W. H. Freeman and Co., New York.

56. Tamura, K., Dudley, J., Nei, M., and Kumar, S. 2007. MEGA4: Molecular evolutionary genetics analysis (MEGA) software version 4.0. Mol. Biol. Evol. 24:1596-1599.

57. Thompson, J. D., Higgins, D. G., and Gibson, T. J. 1994. CLUSTAL W: Improving the sensitivity of progressive multiple sequence alignment through sequence weighting, position specific gap penalties and weight matrix choice. Nucleic Acids Res. 22:4673-4680.

58. Thresh, J. M. 1982. Cropping practices and virus spread. Annu. Rev. Phytopathol. 20:193-216.

59. Woodson, R. E., Jr. 1954. The North American species of Asclepias L. Ann. Mo. Bot. Gard. 41:1-211.

60. Wren, J. D., Roossinck, M. J., Nelson, R. S., Scheets, K., Palmer, M. W., and Melcher, U. 2006. Plant virus biodiversity and ecology. PLoS Biol 4:e80.

61. Yuan, J. S., Tiller, K. H., Al-Ahmad, H., Stewart, N., and Stewart, C. N., Jr. 2008. Plants to power: Bioenergy to fuel the future. Trends Plant Sci. 13:421-429.

62. Zuckerkandl, E., and Pauling, L. 1965. Evolutionary divergence and convergence in proteins. Pages 97-166 in: Evolving Genes and Proteins. V. Bryson and H. J. Vogel, eds. Academic Press, New York. 